\title{
De novo anaplastic Kaposi sarcoma in a HIV-negative man: A case report and review of the literature
}

\section{Slim Charfi ${ }^{1}$, Hend Chaabane ${ }^{2}$, Ikbel Chaari ${ }^{2}$, Rim Kallel', Hamida Turki ${ }^{2}$, Tahya Sellami Boudawara ${ }^{1}$}

${ }^{1}$ Department of Pathology, CHU Habib Bourguiba, Sfax, Tunisie, ${ }^{2}$ Department of Dermatology, CHU Hedi Chaker, Sfax, Tunisie

Corresponding author: Prof. Slim Charfi, E-mail: charfislim@gmail.com

\begin{abstract}
Anaplastic Kaposi sarcoma is a rare variant of Kaposi's and is typically associated with an agressive clinical course. We report a case of a 67-year-old HIV negative man, presented with multiple, pink nodules on the left ankle and a keratotic lesion of the right heel. Initial histopathological exam concluded to an undifferentiated sarcoma. A second biopsy was performed and concluded to an anaplastic Kaposi sarcoma. Immunohistochemical study was positive for HHV8. Treatment consisted on a tumor excision of all lesions. Our case and the review of the literature highlight the benefit of the non conservative surgical treatment for this aggressive form of Kaposi sarcoma.
\end{abstract}

Key words: Anaplastic; Kaposi; Prognosis; Pathology

\section{INTRODUCTION}

Kaposi sarcoma has the ability to develop into lesions of varying morphologic appearance. Anaplastic variant is the only variant associated with aggressive behaviour [1]. It is important to be able to recognize this variant in order to avoid potential misdiagnosis and improper management of affected patients. We present here a case of anaplastic KS in a HIV negative patient and a review of literature about anaplastic KS.

\section{CASE REPORT}

A 67-year-old man with a history of type 2 diabetes, high blood pressure and deep vein thombosis of the left lower leg presented with multiple $0.5-2 \mathrm{~cm}$, pink nodules, located on the left ankle. On the right heel, we noted akeratotic nodular lesion (Fig. 1). All these lesions had a 2 months history. No lesions were noted in the oral mucosa. Laboratory test showed a biological inflammatory syndrome. HIV serology was negative. Clinical impression was that of Kaposi sarcoma and a punch biopsy of lesions was performed. Pathological report, peformed outside of our department concluded to an undifferentiated sarcoma. A second excisional biopsy was performed. Histopathological exam revealed an epidermal ulceration and dermal proliferation of spindle and epithelioid cells. Tumor cells are arranged in fascicles and solid sheets (Fig. 2). Irregular vascular spaces, suggestive of a vasoformative tumor, were focally noted. There are areas of necrosis. The nuclei were very pleomorphic with variably prominent nucleoli. Numerous mitosis were present (10 mitosis per $10 \mathrm{HPF})$. The stromal component included numerous plasma cells. Immunohistochemical study showed positivity for CD34, CD31 and HHV8 (Fig. 3). The diagnosis of anaplastic KS was made. Additional clinical workup including chest radiography, abdominal ultrasound and computed tomography scan of the chest, abdomen and pelvis were normal. Upper digestive endoscopy was not performed. Treatment has consisted on a complete electrosurgical shave tumor excision. At 13 months of follow-up, the patient was readmitted to our department for a disease progression with a fungiform exophytic mass of the left ankle (Fig. 4). No distant metastatic

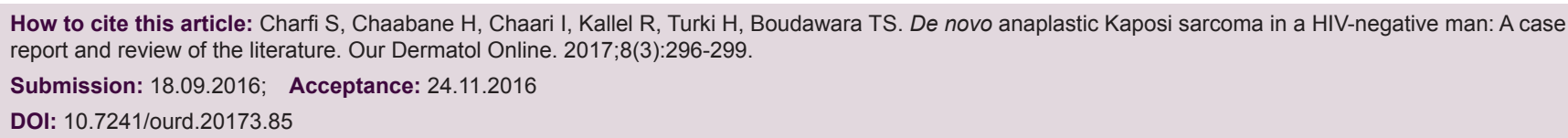




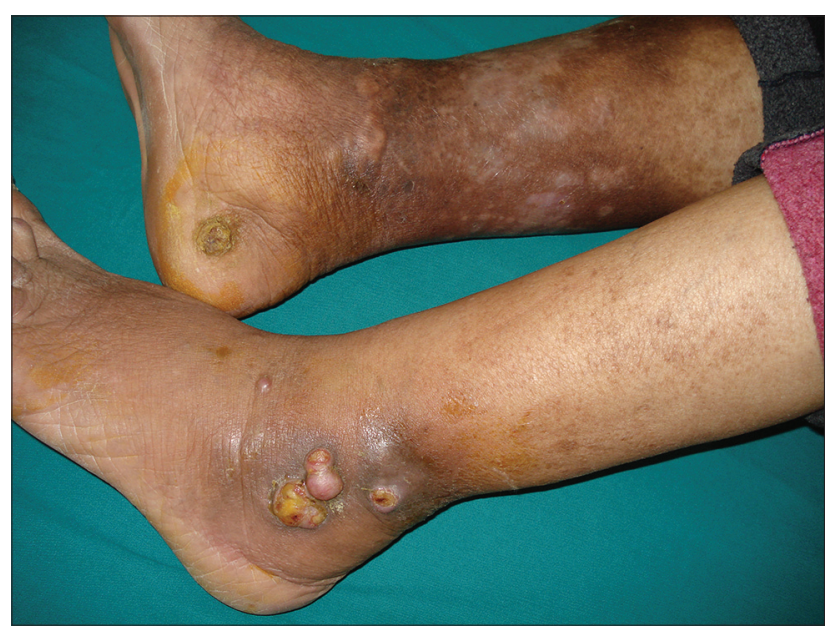

Figure 1: Multiple round to oval, pink nodules on the left ankle; keratotic nodular lesion of the right heel.

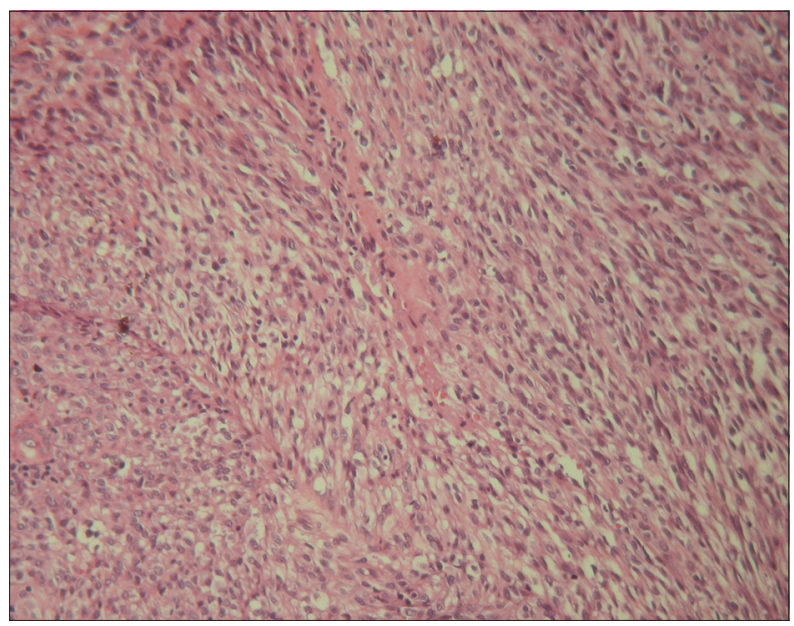

Figure 2: Solid hapharzard proliferation of atypical spindle cells. (HE x 100).

recurrence was noted. A chemotherapy treatment was instaured.

\section{DISCUSSION}

Anaplastic KS was first described in 1959 by Cox and Helwig as KS with increased in the number of mitotic figures and marked cellular pleomorphism [2]. Anaplastic KS is an uncommon histologic variant, representing $0.4 \%$ to $2.7 \%$ of all the patients affected by KS [3-5]. Clinical data regarding all published cases of anaplastic KS with confirmed HHV8 association are detailed in Table 1. Anaplastic KS arises in patients with a history of KS, or de novo. Factors that predispose to anaplastic progression of KS are not well known [3]. Potential inducers, such as a long course of the disease, lymphedema, chemotherapy and immune

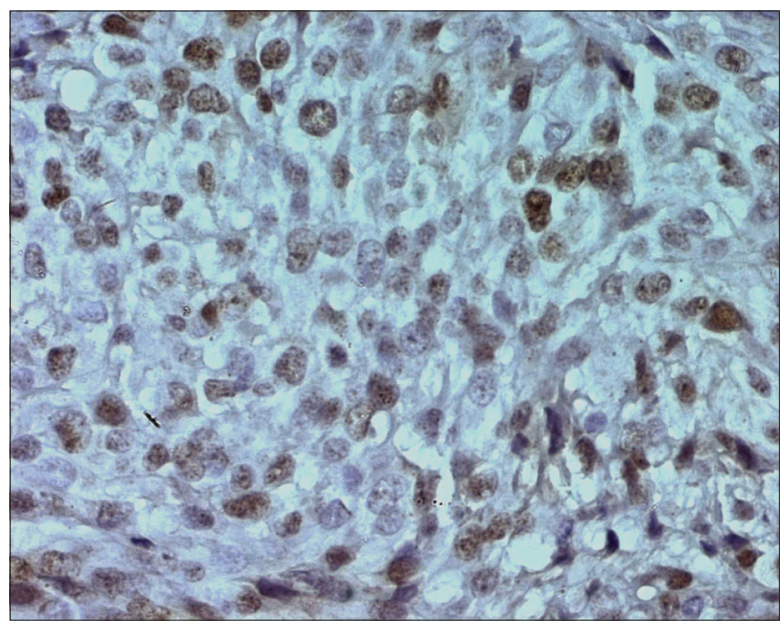

Figure 3: Positive immunohistochemical staining with HHV8. (HE x 400).

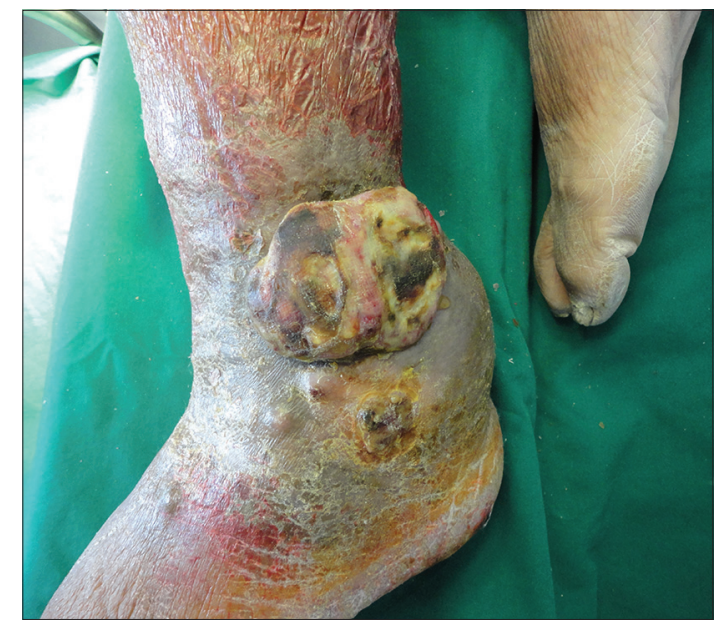

Fig. 4: Fungiform exophytic mass of the left ankle.

system defects in HIV patients are reported [4]. At the best of our knowledge only 14 de novo Anaplasic KS were published [3,5-8]. Nine of these cases were reported by Ramdial et al. [5]. Anaplastic histology has ben described in the context of classic, africain and AIDS-related KS [1]. Anaplastic KS appear to have a predilection for acral location $[3-5,9,10]$. Only three HIV negative patients with de novo anaplastic KS, as our case, were reported $[3,8]$.

Clinical presentation of anaplastic KS is not specific; they present as pink to purple or reddish cutaneous nodules and/or plaques [4,7]. Some authors reported nodular areas growing rapidly to form a confluent fungiform exophytic mass that was in part ulcerated and necrotic [3,5]. Infiltration of the muscle or bone was described [4]. Salameire et al. report a case of 50-year-old woman who presented with several 
www.odermatol.com

Table 1 : Clinical data regarding all published cases of anaplastic Kaposi sarcoma with confirmed HHV8 association

\begin{tabular}{|c|c|c|c|c|c|c|c|c|}
\hline case & Authors & Age/sex & $\begin{array}{l}\text { Time to } \\
\text { progression }\end{array}$ & HIV & Lesion site & Metastasis & Treatment & Outcome \\
\hline 1 & Satta et al. [3] & $85 / M$ & 0 (de novo) & - & Leg & - & Chemotherapy & Died $^{*}$ \\
\hline 2 & & $74 / \mathrm{M}$ & 0 (de novo) & - & Leg & - & chemotherapy & Died $^{*}$ \\
\hline 3 & & $82 / \mathrm{M}$ & 5 & - & Arm & $\begin{array}{l}\text { Spleen, bones, } \\
\text { liver }\end{array}$ & Chemotherapy & Died of KS \\
\hline 4 & & $75 / M$ & 8 & - & Leg & Liver & Chemotherapy & Died of KS \\
\hline 5 & & 78/M & 12 & - & leg & - & Chemotherapy & Alive with KS \\
\hline 6 & Tourlaki et al [4] & $47 / M$ & 21 & - & Leg & - & $\begin{array}{l}\text { Chemotherapy, RT and } \\
\text { amputation }\end{array}$ & Diead of KS \\
\hline 7 & & $76 / F$ & 1 & - & Leg & $\begin{array}{l}\text { Regional lymph } \\
\text { nodes }\end{array}$ & $\begin{array}{l}\text { Chemotherapy and } \\
\text { amputation }\end{array}$ & Died of KS \\
\hline 8 & & $82 / \mathrm{M}$ & 17 & - & Leg & - & $\begin{array}{l}\text { Ifosfamide, epirubicin, } \\
\text { paclitaxel }\end{array}$ & Died of KS \\
\hline 9 & & $68 / \mathrm{M}$ & 17 & - & Leg & $\begin{array}{l}\text { Regional lymph } \\
\text { nodes }\end{array}$ & $\begin{array}{l}\text { Paclitaxel, vinblastine, } \\
\text { amputation, vincristine, } \\
\text { lymphadenectomy }\end{array}$ & CR \\
\hline 10 & & $61 / \mathrm{M}$ & 7 & - & Leg & - & $\begin{array}{l}\text { Vinorelbine, RT, tumor } \\
\text { excision }\end{array}$ & CR \\
\hline 11 & & $66 / M$ & 1 & - & Leg & $\begin{array}{l}\text { Regional lymph } \\
\text { nodes }\end{array}$ & Vinorelbine, amputation & $\mathrm{CR}$ \\
\hline 12 & & $67 / M$ & 22 & - & Legs & $\begin{array}{l}\text { Regional lymph } \\
\text { nodes }\end{array}$ & Amputation, paclitaxel, & $\mathrm{CR}$ \\
\hline 13 & & $84 / F$ & 1 & - & Leg & - & Paclitaxel & $\begin{array}{l}\text { CR, Died of } \\
\text { pneumonia }\end{array}$ \\
\hline 14 & Ramdial et al. [5] & $42 / M$ & 0 (de novo) & + & Leg & NA & NA & $\begin{array}{l}\text { Died of AIDS } \\
\text { cachexia }\end{array}$ \\
\hline 15 & & $31 / F$ & 0 (de novo) & + & Ankle & NA & NA & $\begin{array}{l}\text { Died of } \\
\text { pulmonary } \\
\text { tuberculosis }\end{array}$ \\
\hline 16 & & $22 / M$ & 0 (de novo) & + & Leg & NA & NA & Alive with KS \\
\hline 17 & & $26 / F$ & 0 (de novo) & + & Wrist & NA & NA & $\begin{array}{l}\text { Lost to } \\
\text { follow-up }\end{array}$ \\
\hline 18 & & $47 / M$ & 0 (de novo) & + & Ankle & NA & NA & $\begin{array}{l}\text { Died of AIDS } \\
\text { cachexia }\end{array}$ \\
\hline 19 & & $32 / \mathrm{M}$ & 0 (de novo) & + & Thigh & NA & NA & $\begin{array}{l}\text { Lost to } \\
\text { follow-up }\end{array}$ \\
\hline 20 & & $37 / M$ & 0 (de novo) & + & Leg & NA & NA & $\begin{array}{l}\text { Lost to } \\
\text { follow-up }\end{array}$ \\
\hline 21 & & $30 / F$ & 0 (de novo) & + & Leg & NA & NA & $\begin{array}{l}\text { Died of } \\
\text { pulmonary } \\
\text { tuberculosis }\end{array}$ \\
\hline 22 & & $26 / M$ & 0 (de novo) & + & Thigh & NA & NA & $\begin{array}{l}\text { Lost to } \\
\text { follow-up }\end{array}$ \\
\hline 23 & Yu et al. [7] & $53 / M$ & 0 (de novo) & + & $\begin{array}{l}\text { Face, chest, } \\
\text { abdomen } \\
\text { and Back }\end{array}$ & $\begin{array}{l}\text { Cervical, axillary } \\
\text { and inguinal lymph } \\
\text { nodes, lungs }\end{array}$ & $\begin{array}{l}\text { Chemotherapy (liposomal } \\
\text { doxorubicin) }\end{array}$ & Died of KS \\
\hline 24 & Salameire et al. [8] & $50 / F$ & 0 (de novo) & - & arm & - & $\begin{array}{l}\text { Elastic contension and } \\
\text { liposomal doxorubicin }\end{array}$ & $\mathrm{CR}$ \\
\hline 25 & raddock et al.[9] & $43 / \mathrm{M}$ & 13 & + & legs & - & $\begin{array}{l}\text { Liposomal doxorubicin } \\
\text { paclitaxel }\end{array}$ & Alive with KS \\
\hline 26 & Gambasi et al [10] & $82 / \mathrm{M}$ & 0.5 & - & feet & stomach & Vinblastine & Died of KS \\
\hline 27 & Cerimele et al [12] & $55 / \mathrm{M}$ & 28 & - & arm & - & $\begin{array}{l}\text { Etoposide mitoxantrone } \\
\text { arm amputation }\end{array}$ & CR \\
\hline 28 & Our case & $67 / \mathrm{M}$ & 0 (de novo) & - & Ankle & - & Tumor excision & Alive with KS \\
\hline
\end{tabular}

nodules on lymphedematous arm, 2 yeras after a left mastectomy and a homolateral lymphadenectomy, mimicking a stewart-treves syndrome [8].

Anaplastic KS dispalys a significantly greater degree of nuclear and cellular pleomorphism than conventional

(c) Our Dermatol Online 3.2017 nodular KS $[1,11]$. In addition, there is an increased mitotic activity (mitotic figures range from 10 to 20 per $10 \mathrm{hpf}$ ) and atypical mitosis may be encountered (radu, grayson). Necrosis is occasionally noted [9]. The stromal component, like that of classical KS and as reported in our case is plasma cell-rich and contains 
extravasated erythrocytes [7]. The vasoformative nature of anaplastic KS is not readly apparent. As in our report, Ramdial et al. reported three cases of anaplastic $\mathrm{KS}$ with initial erronous diagnosis (malignant peripheral nerve sheath tumor in two cases and metastatic melanoma in one case). In fact, many other malignant spindle cell neoplasms might be entertained in the histologic differential diagnosis of anaplastic KS. It includes certain sarcomas (leiomyosarcoma, spindle cell rhabdomyosarcoma, malignant peripheral nerve sheath tumor, fibrosarcoma), amelanotic spindle cell melanoma, especially when present on acral sites andspindle cell carcinoma [5]. Angiosarcoma must also be considered, particularly if erythrocytes are identified between the markedly atypical spindled cells [9]. A panel of immunohistochemical stains is often required to confirm the diagnosis of anaplastic KS. This panel must include HHV8. Immunostaining for S100 protein can lead to diagnostic pitfalls; in fact Ramdial et al demonstrates the presence of S100 positive cells corresponding to langerhans cells in anapalstic KS [5].

Anaplastic KS is clinically associated with high local aggressiveness, deep invasion and increased metastatic behavior $[1,3,7]$. Considering our case and those described in the literature, we observe that among 28 patients with anaplastic KS, 9 died of anaplastic $\mathrm{KS}, 7$ died of other causes (including four HIV positive patients) and 2 were alive with anaplastic KS [3-5,7-10,12]. Satta et al. supported an intrinsic genetic instability of the malignant cell resulting in clonal progression of the neoplastic phenotype [3]. Craddock et al. reports that anaplastic portion of the KS respond well to paclitaxel and no liposomal doxorubicin, while the background typical KS lesions have had the opposite behaviour with these two therapies [9]. In the report of Salameire et al, a total regression of the lesion was obtained by elastic contention and intradermic liposomal doxorubicin [8]. Tourlaki et al recommend an aggressive approch, more specifically a non-conservative surgical treatment associated with systemic chemotherapy. Amputation due to deep tissue invasion may be required [4]. Our patient treated with only tumor excision, a frankly disease progression was noted at 13 months of diagnosis.
Anaplastic variant of $\mathrm{KS}$ is a poorly recognized associated to an aggressive clinical course and poor prognosis. Histopathological differential diagnoses include numerous undifferentiated high grade malignancies. Non conservative surgical treatment seems appropriate for these patients.

\section{Consent}

The examination of the patient was conducted according to the Declaration of Helsinki principles.

\section{REFERENCES}

1. Grayson W, Pantanowitz L. Histological variants of cutaneous Kaposi sarcoma. Diagn Pathol. 2008;3:31.

2. Cox FH, Helwig EB. Kaposi's sarcoma. Cancer. 1959;12:289-98.

3. Satta R, Cossu S, Massarelli G, Cottoni F. Anaplastic transformation of classic Kaposi's sarcoma: clinicopathological study of five cases. Br J Dermatol. 2001;145:847-9.

4. Tourlaki A, Recalcati S, Boneschi V, Gaiani F, Colombo A, Mancuso R, et al. Anaplastic Kaposi's sarcoma: a study of eight patients. Eur J Dermatol. 2013;23:382-6.

5. Ramdial PK, Sing Y, Naicker S, Calonje E, Sewram V, Singh B. Langerhans cells in anaplastic Kaposi sarcoma with a paucivascular phenotype: a potential diagnostic pitfall. Pathol Int. 2011;61:221-7.

6. Smith KJ, Skelton HG 3rd, James WD, Barrett TL, Anderson DW, Angritt P. Angiosarcoma arising in Kaposi's sarcoma (pleomorphic Kaposi's sarcoma) in a patient with human immunodeficiency virus disease. Armed Forces Retroviral Research Group. J Am Acad Dermatol. 1991;24:790-2.

7. Yu Y, Demierre MF, Mahalingam M. Anaplastic Kaposi's sarcoma: an uncommonhistologic phenotype with an aggressive clinical course. J Cutan Pathol. 2010;37:1088-91.

8. Salameire D, Templier I, Charles J, Pinel N, Morand P, Leccia MT, et al. An "anaplastic" Kaposi's sarcoma mimicking a StewartTreves syndrome. A case report and a review of literature. Am J Dermatopathol. 2008;30:265-8.

9. Craddock KJ, Labonte S, Ghazarian D. Anaplastic Kaposi sarcoma resembling epithelioid angiosarcoma in an HIV-positive man. Eur J Dermatol. 2008;18:358-9.

10. Gambassi G, Semeraro R, Suma V, Sebastio A, Incalzi RA. Behavior of Classical Kaposi's Sarcoma and Coexistence With Angiosarcoma. J Gerontol A Biol Sci Med. 2005;4:520-3

11. Radu O, Pantanowitz L. Kaposi sarcoma. Arch Pathol Lab Med. 2013;137:289-94.

12. Cerimele D, Carlesimo F, Fadda G, Rotoli M, Cavalieri S. Anaplastic progression of classic Kaposi's sarcoma. Dermatology. 1997;194:287-9.

Copyright by Slim Charfi, et al. This is an open-access article distributed under the terms of the Creative Commons Attribution License, which permits unrestricted use, distribution, and reproduction in any medium, provided the original author and source are credited.

Source of Support: Nil, Conflict of Interest: None declared. 